\title{
The Effect of Return On Assets and Return On Equity To Earning Per Share and Price Book Value In Sub-Sectors of Construction Companies Listed In Indonesia Stock Exchange In 2015-2018
}

\author{
Shofi Malina, ${ }^{\mathrm{a},{ }^{*}}$ I Gede Arimbawa ${ }^{\mathrm{b}}$, Ani Wulandari ${ }^{\mathrm{c}}$ \\ ${ }^{a}$ Faculty of Economics and Business, Narotama University, Jl Arief Rachman Hakim 51, Sukolilo, Surabaya,Indonesia \\ ${ }^{b}$ Faculty of Economics and Business, Narotama University, Jl Arief Rachman Hakim 51, Sukolilo, Surabaya, Indonesia \\ ${ }^{c}$ Faculty of Economics and Business, Narotama University, Jl Arief Rachman Hakim 51, Sukolilo, Surabaya, Indonesia
}

\begin{abstract}
The purpose of the research is to analyze the effect of return on assets and return on equity on earnings per share and price book value in building construction sub sector companies listed on the Indonesia Stock Exchange in 2015-2018. The population of this research was the building construction companies listed on the Indonesia Stock Exchange during 2015-2018. The sample used was 10 construction companies with a purposive sampling method. Data collection techniques used in the documentation were in the form of secondary data and library research. The analysis was using path analysis. It was revealed that the return on assets has a significant negative effect and return on equity have a significant positive effect on earnings per share. While return on equity has a significant positive effect and earnings per share has a significant negative impact on price book value. However, return on assets does not have a significant effect on price book value.
\end{abstract}

Keywords: Return on Asset, Return on Equity, Earning per Share dan Price book Value

\section{Introduction}

Company Value is the company's performance which is reflected by the price of shares formed by capital market demand and supply that reflects the public's assessment of the company's performance (Harmono, 2009). Thus the stock price is a reflection of the value of a company. The higher the stock price the higher the value of the company, conversely the lower the stock price, the company value is also low or the company's performance is not good. Company value can be measured by price to book value (PBV), which is a ratio used to measure the performance of stock prices against the book value (Ang, 1997). The higher the value of the Price Book Value ratio the higher the valuation of investors compared to the funds invested in the company, therefore the greater the opportunity for investors to purchase company shares. The company's success in creating value certainly gives hope to shareholders in the form of greater profits as well (Sartono, 2001). Price book value helps investors determine which shares are fair, overvalued, or undervalued, in other words, Price Book Value can provide an indication of investors' views of the company.

The construction sector is one of the four main business sectors that are developing in Indonesia that may attract foreign investment. The following is the development of the value of the company Construction of buildings listed on the Indonesian stock exchange (BEI) which is shown to have a Price book Value:

\footnotetext{
* Corresponding author.

E-mail address: shofimalina@gmail.com (Shofi Malina)
} 


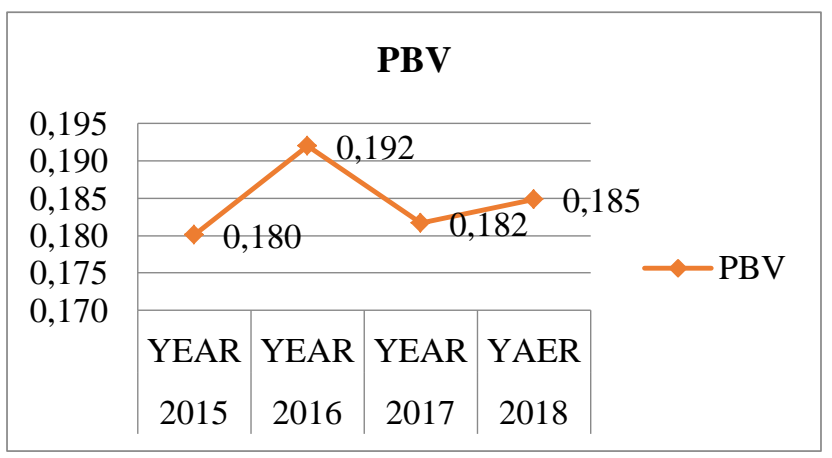

Fig. 1. PBV Data for Building Construction Companies in 2015-2018 Source: (www.idx.co.id)

Based on the graph table 1 Price Book Value Value in Building Construction Sub Sector Companies experiencing fluctuating movements. In 2015 the average Price Book Value was 0.180\%, up in 2016 to $0.192 \%$. However, it decreased in 2017 to 0.182 and experienced a slight increase in 2018 to $0.185 \%$. This means that in general, the company's value projected by Price Book Value is not good enough. A fine Price Book Value is generally above one which indicates a stock market value greater than the book value of a company, with a high Price Book Value the higher the inversor rating will be, compared to the funds invested in the company.

In measuring financial performance, financial ratios that are often used profitability ratios including return on assets (ROA) and return on equity (ROE). Return on assets measures the return on total assets after interest and taxes. The return on total assets or total investment that displays the performance of management in using company assets to generate profits. While Return on equity shows the success or failure of management in maximizing the rate of return on investment of shareholders and emphasizes the results of income in relation to the amount invested. (Abd'rachim, 2008).

The results of an empirical study of pricebook valuation exhibit that the profitability ratio (Return on assets and return on equity) significantly influence the price book value (Herman dan Michael, 2010). The results of this study are strengthened by research conducted by Sundus and Euis, 2017 that the return on asset (ROA) variable has a significant effect on the value of the company represented by the price book value at commercial banks. Whereas based on research conducted by Oktrima, 2017 shows that profitability which is proxied by return on assets (ROA) does not affect the Company Value that is proxied by Price Book Value (PBV) at PT. Mayora Indah, Tbk and research conducted by Panca and Maduretno, 2016 displayed that Return on equity (ROE) had a significant negative effect on the value of the company represented by the price book value of the SOEs. The results of the study above appear to be independent variables ROA and ROE have different effects on price book value thus the authors want to reexamine the effect of Return on assets (ROA) and Return on equity (ROE) on Price Book Value (PBV) by adding intervening variable which is Earning per share (EPS).

\section{Literature Review}

\subsection{Price Book Value (PBV)}

The main purpose of the company according to the theory of the firm is to maximize the company's wealth or value (value of the firm). The value of the company is defined as market value because the value of the company can provide maximum prosperity for shareholders if the company's stock price increases. Various policies taken by management in an effort to increase the value of the company through increasing the prosperity of owners and shareholders as reflected in the share price (Brigham, Eugene, \& F.Houston, 2006:19). Company value can be measured by price to book value (PBV), which is a ratio used to measure the performance of stock prices against the book value (Ang, 1997). The higher the value of the Price Book Value ratio the higher the valuation of investors compared to the funds invested in the company, hence the greater the opportunity for investors to buy company shares. Price to book value is one of the variables that investors consider in determining which stocks to purchase. The 
value of the company can provide maximum profit shareholders if the company's stock price increases. The higher the stock price, the higher the shareholder wealth.

\subsection{Return On Asset (ROA)}

Retrun on asset is used to measure the ability of management in obtaining overall profits (profits) (Margaretha, 2007), The greater the return on assets, the more profit levels will be achieved. If the company's ability to use its assets to increase profits directly and indirectly will affect the increase in a company's net profit. This is supported by research results Sriyono et al., (2019) which states that the variable return on assets has a significant effect on earnings per share. The results of these studies differ from studies Diaz, (2008) shows that Return On Asset (ROA) has a negative effect on Earning Per Share. With this, the researcher wants to know the relationship between Return On Assets and Earning Per Share based on the theory and empiricism above, the author formulates a hypothesis:

Hypothesis 1: Return on assets has a significant effect on earnings per share

Return on assets is a ratio that is used to measure the company's ability to generate profits derived from investment activities (Mardiyanto, 2009). The greater the Return on assets, the greater the level of excellence achieved by the company and the better the company's position in terms of asset use. This theory is also strengthened by research conducted Halimah \& Komariah, (2017) which results that the Return on assets has a significant influence on the price book value. While based on research conducted by Oktrima, (2015) exhibits that profitability proxied by return on assets (ROA) does not affect the value of the company which is proxied by Price Book Value (PBV). With this researcher would like to explore the relationship between Return On Assets and Price Book Value based on the theory and empirical above, the author formulates a hypothesis:

Hypothesis 2: Return On Asset has a significant effect on Price Book Value

\subsection{Return On Equity (ROE)}

Return on euity is one of the factors that Earning per share (Husnan, 2001). This can be seen from the calculation formula that the numerator earnings per share with the numerator return on equity, so that if return on equity is multiplied by the book value per share, then the value will be the same as earnings per sahre. It can be said that with the variable return on equity, it will be followed by an increase in earnings per share, and if Return on equity decreases, earnings per share will also be decreased. This theory is also strengthened by research conducted Lestiningsih, (2017) which states that Return on equity has a significant effect on earnings per share. However, based on research Sriyono, Prapanca, \& Budi, (2019) The research shows that the partial return on equity test does not have a significant effect on earnings per share. With this researcher would like to reveal the relationship between Return On Equity with Earning per share based on the theory and empirical above, the author formulates a hypothesis:

Hypothesis 3: Return On Equity significantly influences Earning Per Share

Besides being one of the factors that earns earnings per share, this profitability ratio (Return On Equity) is a financial ratio that connects earnings with investment. High profitabilitypreflects the company's ability tougenerate high profits for shareholders. With the high profitability ratio owned by the company can attract investors to invest in the company. This statement is backboned by the empirical results which give the result that the return on equity variable has a significant influence on the price book value(Michael \& Ruslim, 2019). This research is different from the research conducted by Wahyuningsih \& Widowati, (2016) shows that Return on Equity (ROE) has a significant negative effect on the value of a company represented by the price book value of a State-Owned Enterprise (BUMN). Hereby researchers would like to examine the relationship between Return on Equity and Price Book Value based on the theory and empiricism above, the author formulate a hypothesis:

Hypothesis 4: Return On Equity significantly influences the Price Book Value

\subsection{Earning Per Share}

Earnings per share are widely used in evaluating the operating performance and profitability of a company (Wild \& Subramanyam, 2005). High and low Earning per share depends on the net profit generated by the company. Companies that generate large net profits show good performance in the eyes of investors. The greater the value of 
Earning Per Share, the greater the returns received by investors so that the more attractive the stock causes the demand for shares to increase. High demand for shares causes the stock price to rise and increases the value of the Price Book Value which is measured based on the stock price. This theory is also strengthened by research conducted Septiani \& Wijaya, (2018) which says that Earning Per Share (EPS) has a positive effect on increasing the Price Book Value. However the results of the study are different Pioh, Tommy, \& Sepang, (2018) The research displays that Earning Per Sahre has no significant effect on Company Value which is represented by Price book value in Food and Bavarege sector companies listed on the Indonesia Stock Exchange in 2013-2017. Hereby the researcher would like to know the relationship between Earning Per Share and Price Book Value based on theory and Empirical above, the author formulates a hypothesis:

Hypothesis 5: Earning Per Share has a significant effect on Price Book Value.

\section{Research Conceptual Framework}

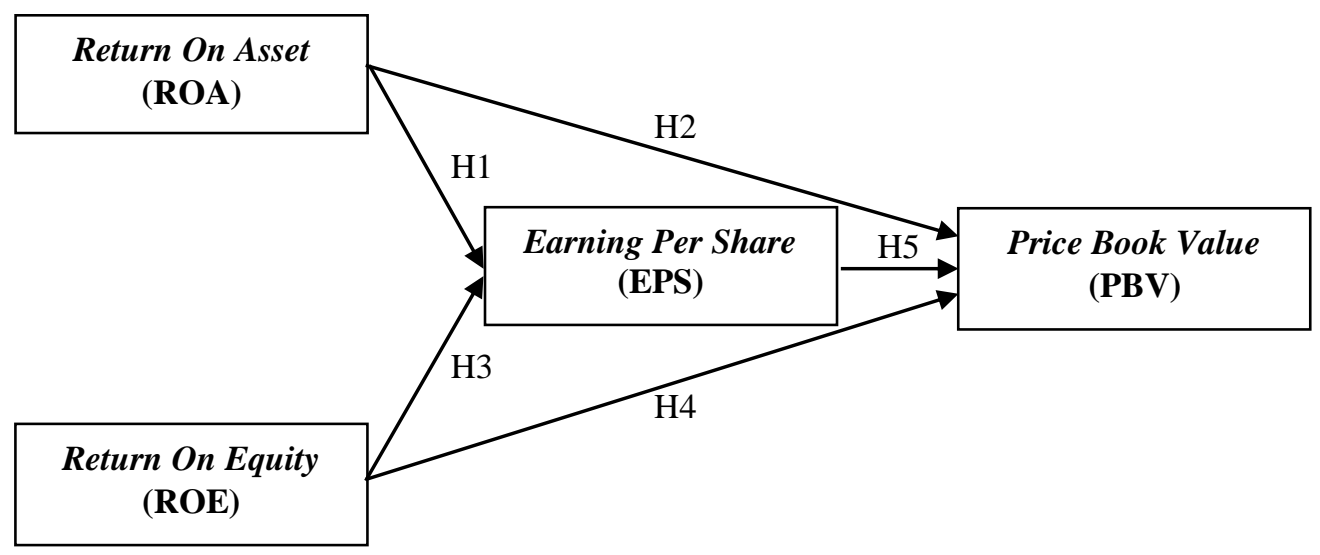

Fig. 1: Conceptual Thinking Framework Source : Author

\section{Methodology}

This research is quantitative descriptive using external secondary data as research material. The secondary data used is in the form of financial statements of the 2015-2018 building construction sub-sector listed on the Indonesia Stock Exchange. In this study the data includes Return On Assets (ROA) and Return On Equity (ROE) as an independent variable, Earning Per Share (EPS) as an intervening variable and Price Book Value (PBV) as the dependent variable. The sampling method using purposive sampling method, with a total sample of 10 companies that meet the criteria of 16 companies. Samples are selected based on selection criteria.

Data collection techniques are the most strategic step in research, because the main purpose of research is to collect data (Sugiyono, 2009:224). Data collection techniques in this study is documentation techniques. The documentation method is used to collect financial reports in the Building Construction sub-sector companies in 2015-2018 on the site www.idx.co.id. The second data collection method used in this study is library research. Literature research is a way to collect data through library media in the form of Company Annual Reports, books, journals and other literature relating to the matter examined.

Data analysis techniques used path analysis with the Statistical Package Social Sciences (SPSS) version 18 program, before the data were tested first with the normality test. Hypothesis testing is done by using the $\mathrm{t}$ test, $\mathrm{F}$ test, and the coefficient of determination test. The path coefficient is calculated by making two structural equations, namely the regression equation which shows the hypothesized relationship. The steps to test the path analysis are as follows: (Pardede \& Manurung, 2014). 
1. Substructure Analysis 1

$Y 1=\beta Y 1 X 1+\beta Y 1 X 2+e 1$

Where :

$$
\begin{array}{ll}
\mathrm{Y} 1 & =\text { Earning Per Share } \\
\mathrm{X} 1 & =\text { Return On Asset } \\
\mathrm{X} 2 & =\text { Return On Equity } \\
\mathrm{e} 1 & =\text { Error }
\end{array}
$$

2. Substructure Analysis 2

$Y 2=\beta Y 2 X 1+\beta Y 2 X 2+e 2$

Where :

Y2 = Price Book Value

$\mathrm{X} 1=$ Return On Asset

$\mathrm{X} 2=$ Return On Equity

e2 = Error

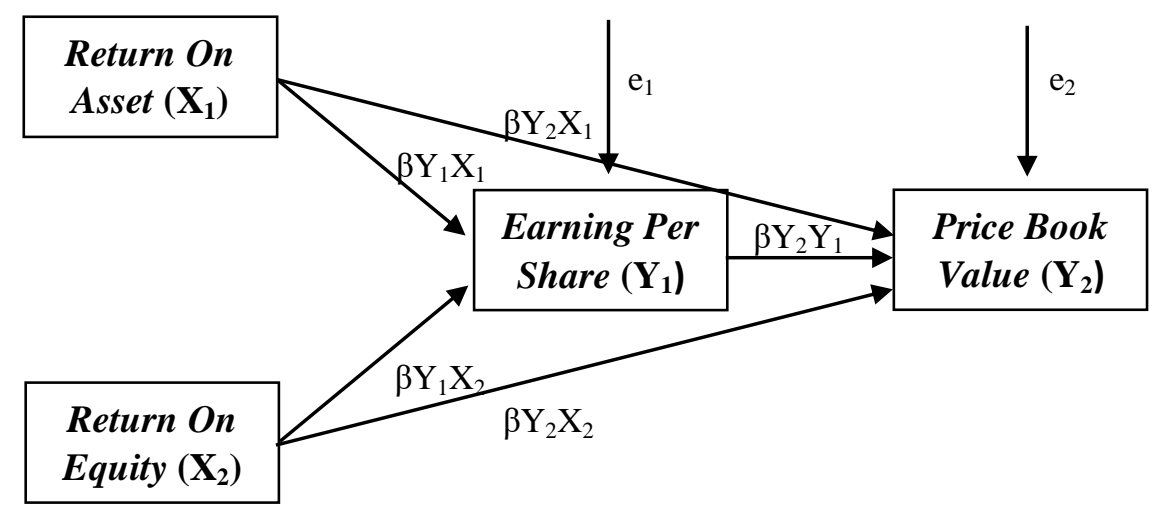

Fig. 2. Path Diagram Model

Source :(Pardede \& Manurung, 2014)

\section{Operational Definition}

\section{Return on Asset (X1)}

Return on Assets or also called economic profitability is defined as operating profit with own capital and foreign capital used to generate profits. The indicators in this research are to measure the ability of company management in obtaining overall profits in a company in 10 Building Construction sub-sector Companies. Return on Assets are formulated as follows (Husnan, 2004:72) :

$$
\text { ROA }=\frac{\text { Net } \text { Profit }}{\text { Total Assets }} \times 100 \%
$$

\section{Return on Equity (X2)}

Return on equity is defined as the ratio used to measure the net profit gained from the manager of the capital invested by the owner of the company. The indicators in this study are used by investors in making business decisions on companies in 10 Building Construction sub-sector companies. Return On Equity is formulated as follows (Abd'rachim, 2008) : 


\section{Earning Per Share (Y1)}

$$
\mathrm{ROE}=\frac{\text { Net } \text { Profit }}{\text { Total } \text { Capital }} \times 100 \%
$$

A measure of a company's ability to generate profits per shareholder. Earning Per Share (EPS) is a comparison between net income after tax and the number of shares issued. Earning per share is defined as profit per share owner in 10 Building Construction sub-sector companies. Following formula in calculating EPS(Kasmir, 2012:207):

\section{Price to book value (Y2)}

$$
\text { EPS }=\frac{\text { Net Profit-Special Stock Devidends }}{\text { Weighted average of shares }} \times 100 \%
$$

Price book value illustrates how much the market appreciates the book value of a company's shares in 10 companies in the building construction sub sector. Indicators in this study measure by comparing the stock price to the book value per share. The higher this ratio shows the market believes in the company's prospects. The formula for calculating PBV is as follows(Brigham et al., 2006):

$$
\text { Price Book Value }(\mathrm{PBV})=\frac{\text { Market Price Sheet }}{\text { Book stock value }}
$$

\section{Research and Discussion}

\subsection{Normality test}

Normality test is conducted with the aim to test whether the dependent, intervening and independent variables have normal data distribution or not. In this test it is used to test whether the data is normal or near normal, which can be done using non-parametric statistical tests.

\begin{tabular}{|c|c|c|c|c|c|}
\hline & & $\begin{array}{c}\text { Return On } \\
\text { Asset }\end{array}$ & $\begin{array}{l}\text { Return On } \\
\text { Equity }\end{array}$ & $\begin{array}{c}\text { Earning } \\
\text { Per Share }\end{array}$ & $\begin{array}{c}\text { Price Book } \\
\text { Value }\end{array}$ \\
\hline 1 & & 40 & 40 & 40 & 40 \\
\hline & Mean & 0,526 & 0,9677 & 1,8447 & $-0,9009$ \\
\hline Parameters ${ }^{\mathrm{a}, \mathrm{b}}$ & $\begin{array}{c}\text { Std. } \\
\text { Deviation }\end{array}$ & 0,40051 & 0,3878 & 0,53455 & 0,3795 \\
\hline Most & Absolute & 0,107 & 0,177 & 0,229 & 0,101 \\
\hline $\begin{array}{c}\text { Extreme } \\
\text { Differences }\end{array}$ & Positive & 0,081 & 0,099 & 0,103 & 0,101 \\
\hline & Negative & $-0,107$ & $-0,177$ & $-0,229$ & $-0,071$ \\
\hline Kolmogoro & Smirnov Z & 0,674 & 1,117 & 1,448 & 0,64 \\
\hline Asymp. Si & (2-tailed) & 0,754 & 0,165 & 0,18 & 0,807 \\
\hline
\end{tabular}

Table 1. Normality Test Results

One-Sample Kolmogorov-Smirnov Test

a. Test distribution is Normal.

b. Calculated from data.

Source: SPSS data processing results

Normality test data shows that the four variables, namely Return On Assets, Return On Equity, Earning per Share and Price Book Value are normally distributed because the Asymp value, Sig Residual $>0.05$. 


\subsection{Path Analysis}

Path analysis is an extension of multiple linear regression analysis, or path analysis is an expansion of regression analysis to estimate the quality relationships between variables that have been predetermined based on theory (Ghozali, 2011). Path analysis model is used to analyze the pattern of relationships between variables with the aim to determine the direct or indirect influence of a set of independent (exogenous) variables on the dependent variable (endogenous)(Achmad, Kuncoro, \& Riduwan, 2014:2).

1. Direct Effect

The following is a direct influence on this research model:

Table 2. Results of Direct Effects

\begin{tabular}{cccc}
\hline No & Effect & Relation & Result \\
\hline 1. & Return On Asset to Earning Per Share & $\mathrm{X}_{1} \rightarrow \mathrm{Y}_{1}$ & $-0,683$ \\
2. & Return On Equity to Earning Per Share & $\mathrm{X}_{2} \rightarrow \mathrm{Y}_{1}$ & 1,32 \\
3. & $\mathrm{X}_{1} \rightarrow \mathrm{Y}_{2}$ & $-0,055$ \\
4. & Return On Asset to Price Book Value & $\mathrm{X}_{2} \rightarrow \mathrm{Y}_{2}$ & 0,852 \\
5. & Return On Equity to Price Book Value & $\mathrm{Y}_{1} \rightarrow \mathrm{Y}_{2}$ & $-1,216$
\end{tabular}

Source: Author

2. Indirect Effect

Following are the magnitude of indirect effects on research:

Table 3. Results of Indirect Effects

\begin{tabular}{|c|c|c|c|}
\hline No & Effect & Relation & Result \\
\hline 1. & $\begin{array}{l}\text { Return On Assets to Price Book Value through } \\
\text { Earning Per Share }\end{array}$ & $\mathrm{X}_{1} \rightarrow \mathrm{Y}_{1} \rightarrow \mathrm{Y}_{2}$ & $(-0,683 \times-1,216)=0,83$ \\
\hline 2. & $\begin{array}{l}\text { Return On Equity to Price Book Value through } \\
\text { Earning Per Share }\end{array}$ & $\mathrm{X}_{2} \rightarrow \mathrm{Y}_{1} \rightarrow \mathrm{Y}_{2}$ & $(1,320 x-1,216)=-1,605$ \\
\hline
\end{tabular}

Source : Author

3. Total effect

The total effect is the sum of the direct and indirect effects found in the research model. Here are the total effects on the research model:

Table 4. Total Influence Results

\begin{tabular}{clcc}
\hline No & \multicolumn{1}{c}{ Effect } & Relation & Result \\
\hline 1. & Return On Assets to Price Book Value through Earning & $\mathrm{X}_{1} \rightarrow \mathrm{Y}_{1} \rightarrow \mathrm{Y}_{2}$ & $(-0,683+-1,216)=-1,899$ \\
& Per Share & $\mathrm{X}_{2} \rightarrow \mathrm{Y}_{1} \rightarrow \mathrm{Y}_{2}$ & $(1,320+(-1,216))=0,104$ \\
2. & $\begin{array}{l}\text { Return On Equity to Price Book Value through Earning } \\
\text { Per Share }\end{array}$ & $\mathrm{X}_{1} \rightarrow \mathrm{Y}_{2}$ & 0,055 \\
3. & Return On Asset to Price Book Value & $\mathrm{X}_{2} \rightarrow \mathrm{Y}_{2}$ & 0,852 \\
4. & Return On Equity to Price Book Value & $\mathrm{Y}_{1} \rightarrow \mathrm{Y}_{2}$ & $-1,216$ \\
5. & Earning per share to Price book value & & \\
\hline
\end{tabular}

Source : Author 
Based on the three influences above, it is known that the direct effect given by Return on Assets to Price Book Value is -0.055 and the indirect effect of Return On Assets through Earning Per Share to Price Book Value is 0.830. This means that the value of indirect influence is greater than the direct effect, and also this proves that Return on Assets through Earning per Share has a significant effect on Price Book Value. While the direct effect given on Return on Equity to the Price Book Value of 0.852 and the indirect effect of Return on Equity through Earning per Share to Price Book Value of - 1,605. This also means that the value of the indirect effect is greater than the direct effect, and it also proves that Return on Equity through Earning per Share has a significant effect on the Price Book Value even if it has a negative effect.

\subsection{Simultaneous Test}

Simultaneous Test (Test F) is used to test together whether or not the influence of independent variables on the dependent variable can be known by using the F test (Ghozali, 2011). The measurement is used if the significance probability $>0.05$ then there is no significant influence or $\mathrm{H} 0$ is accepted and $\mathrm{Ha}$ is rejected and if the significance probability $<0.05$ then there is a significant effect or $\mathrm{HO}$ is rejected and $\mathrm{Ha}$ is accepted. The level of significance in this study was $\alpha=0.05$ or $5 \%$ with degrees of freedom $(\mathrm{k} ; \mathrm{n}-\mathrm{k}-1) \quad \mathrm{df}=3 ; 26$. In table $\mathrm{F}$ for $\mathrm{df} 1=3$, df $2=36$, the Ftable value of 2.87 is obtained. Simultaneous Test Results are shown in the following table:

\section{Effect of Return on Assets and Return on Equity on Earning per Share (Substructure 1)}

Table 5. Substructure Determination Coefficient Results 1

\begin{tabular}{|c|c|c|c|c|c|c|c|c|c|c|}
\hline \multicolumn{11}{|c|}{ Model Summary } \\
\hline \multirow[b]{2}{*}{ Model } & & \multirow[b]{2}{*}{$\mathrm{R}$} & \multirow[b]{2}{*}{ R Square } & \multirow{2}{*}{$\begin{array}{c}\text { Adjusted } \\
\text { R } \\
\text { Square }\end{array}$} & \multirow{2}{*}{$\begin{array}{l}\text { Std. } \\
\text { Error of } \\
\text { the } \\
\text { Estimate }\end{array}$} & \multicolumn{5}{|c|}{ Change Statistics } \\
\hline & & & & & & $\begin{array}{c}\mathrm{R} \\
\text { Square } \\
\text { Change }\end{array}$ & $\begin{array}{c}\mathrm{F} \\
\text { Change }\end{array}$ & df1 & $\mathrm{df} 2$ & $\begin{array}{l}\text { Sig. F } \\
\text { Change }\end{array}$ \\
\hline dimension0 & 1 &, $746^{\mathrm{a}}$ & 0,557 & 0,533 & 0,36532 & 0,557 & 23,25 & 2 & 37 & 0 \\
\hline
\end{tabular}

a. Predictors: (Constant), Return On Equity, Return On Asset

Source: SPSS data processing results

Table 6. Substructure F Test Results 1

\begin{tabular}{|c|c|c|c|c|c|c|}
\hline \multicolumn{7}{|c|}{ ANOVA $^{\mathrm{b}}$} \\
\hline Model & & $\begin{array}{l}\text { Sum of } \\
\text { Squares }\end{array}$ & df & $\begin{array}{l}\text { Mean } \\
\text { Square }\end{array}$ & $\mathrm{F}$ & Sig. \\
\hline \multirow{3}{*}{1} & Regression & 6,206 & 2 & 3,103 & 23,25 &, $000^{\mathrm{a}}$ \\
\hline & Residual & 4,938 & 37 & 0,133 & & \\
\hline & Total & 11,144 & 39 & & & \\
\hline
\end{tabular}

a. Predictors: (Constant), Return On Equity, Return On Asset

b. Dependent Variable: Earning Per Share

Source: SPSS data processing results

1) The magnitude of the number $R$ square $\left(r^{2}\right)$ is 0.557 . This number is used to determine the effect of Return On Assets and Return On Equity on Earning per share by calculating the coefficient of determination (KD) using the following formula:

$$
\begin{aligned}
& \mathrm{KD}=\mathrm{r}^{2} \times 100 \% \\
& \mathrm{KD}=0.557 \times 100 \%
\end{aligned}
$$




$$
\mathrm{KD}=55.7 \%
$$

This number means that the effect of Return on Assets and Return on Equity to Earning per share simultaneously is $55.7 \%$. While the remaining $44.3 \%(100 \%-55.7 \%)$ is influenced by other factors. In other words the Earning per share variable that can be explained by using the Return on Asset and Return on Equity variable of $55.7 \%$, while the effect of $44.3 \%$ is caused by other variables outside this model

2) From the results of table 6 above shows that the results of the significance of $0,000<0.05$ and obtained a Fcount value of 23.250 , thus $F_{\text {count }}>F_{\text {table }}(23.250>2.87)$ so that $\mathrm{H} 0$ is rejected and $\mathrm{Ha}$ is accepted. Hence from the above analysis it can be concluded that there is a significant influence on the variable Return on assets and return on equity on earnings per share

\section{Effect of Return on Assets, Return on Equity Earning per Share on Price Book Value (Substructure 2)}

Table 7. Substructure Determination Coefficient Test Results 2

\begin{tabular}{|c|c|c|c|c|c|c|c|c|c|c|}
\hline \multirow[b]{2}{*}{ Model } & & \multirow[b]{2}{*}{$\mathrm{R}$} & \multirow[b]{2}{*}{$\begin{array}{c}\mathrm{R} \\
\text { Square }\end{array}$} & \multirow{2}{*}{$\begin{array}{c}\text { Adjusted } \\
\text { R } \\
\text { Square }\end{array}$} & \multirow{2}{*}{$\begin{array}{l}\text { Std. } \\
\text { Error of } \\
\text { the } \\
\text { Estimate }\end{array}$} & \multicolumn{5}{|c|}{ Change Statistics } \\
\hline & & & & & & $\begin{array}{c}\mathrm{R} \\
\text { Square } \\
\text { Change }\end{array}$ & $\begin{array}{c}\mathrm{F} \\
\text { Change }\end{array}$ & df1 & $\mathrm{df} 2$ & $\begin{array}{c}\text { Sig. F } \\
\text { Change }\end{array}$ \\
\hline dimension0 & 1 &, $868^{\mathrm{a}}$ & 0,754 & 0,733 & 0,196 & 0,754 & 36,736 & 3 & 36 & 0 \\
\hline
\end{tabular}

a. Predictors: (Constant), Earning per Share, Return on Asset, Return on Equity

Source: SPSS data processing results

Table 8. Sub-Structure F Test Results 2

\begin{tabular}{llrrrrr}
\hline \multicolumn{1}{c}{ ANOVA $^{\mathrm{b}}$} & & & & & \\
\hline \multirow{2}{*}{ Model } & $\begin{array}{c}\text { Sum of } \\
\text { Squares }\end{array}$ & df & $\begin{array}{c}\text { Mean } \\
\text { Square }\end{array}$ & F & Sig. \\
\hline \multirow{2}{*}{$\begin{array}{l}\text { Regression } \\
1\end{array}$} & Residual & 4,234 & 3 & 1,411 & 36,736 &, $000^{\mathrm{a}}$ \\
& Total & 1,383 & 36 & 0,038 & & \\
\hline
\end{tabular}

a. Predictors: (Constant), Earning per Share, Return on Asset, Return on Equity

b. Dependent Variable: Price Book Value

Source: SPSS data processing results

1) The magnitude of the number $R$ square $\left(r^{2}\right)$ is 0.733 . This figure is used to determine the effect of Return On Assets, Return On Equity and Earning per share on Price book value by calculating the coefficient of Determination $(\mathrm{KD})$ using the following formula:

$$
\begin{aligned}
& \mathrm{KD}=\mathrm{r}^{2} \times 100 \% \\
& \mathrm{KD}=0.733 \times 100 \% \\
& \mathrm{KD}=73.3 \%
\end{aligned}
$$

This number means that the effect of Return on Assets, Return On Equity and Earning per share on Earning per sha Price book value simultaneously is $77.3 \%$. While the remaining $22.7 \%(100 \%-77.3 \%)$ is influenced by other factors. In other words, the Price book value variable can be explained by using the Return on Asset, Return On Equity and Earing variables per share of $77.3 \%$, while the effect of $22.7 \%$ is caused by other variables outside this model. 
2) Based on the results of table 8 above shows that the results of the significance of $0,000<0.05$ and the Fcount value obtained was 36.736, thus $\mathrm{F}_{\text {count }}>\mathrm{Ft}_{\text {able }}(23.250>2.87)$ so that $\mathrm{H}_{0}$ is rejected and $\mathrm{Ha}$ is accepted.Therefore from the above analysis it can be concluded that there is a significant influence on the variables Return on assets, return on equity and earnings per share on price book value.

\subsection{T test (Partial Test)}

Partial Test ( $\mathrm{t}$ test) is used to test the presence or absence of the influence of the variable Return on assets, return on equity and earnings per share on the price book value. The guideline used if the significance probability $>0.05$ then no $\mathrm{d}$ significant influence or $\mathrm{HO}$ is accepted and $\mathrm{Ha}$ is rejected and if the significance probability $<0.05$ then there is a significant effect or $\mathrm{H} 0$ is rejected and $\mathrm{Ha}$ is accepted. The significance level of $\alpha=0.05$ or $5 \%$ with degrees of freedom $(\mathrm{df}=\mathrm{n}-\mathrm{k}) \mathrm{df}=40-4=36$, where the value of the two-way test table is 2,028 . Partial Test Results are shown in the following table:

\section{Effect of Return on Assets and Return on Equity on Earning per Share (Substructure 1)}

Table 9. Test Results for Substructure 1

\begin{tabular}{|c|c|c|c|c|c|c|}
\hline \multicolumn{7}{|c|}{ Coefficients $^{\mathrm{a}}$} \\
\hline \multirow{2}{*}{\multicolumn{2}{|c|}{ Model }} & \multicolumn{2}{|c|}{ Unstandardized Coefficients } & \multirow{2}{*}{$\begin{array}{c}\text { Standardized Coefficients } \\
\text { Beta }\end{array}$} & \multirow{2}{*}{$\mathrm{t}$} & \multirow{2}{*}{ Sig. } \\
\hline & & B & Std. Error & & & \\
\hline \multirow{3}{*}{1} & (Constant) & 1 & 0,21 & & 2,66 & 0,012 \\
\hline & Return On Asset & -1 & 0,37 & $-0,683$ & $-2,5$ & 0,017 \\
\hline & Return On Equity & 2 & 0,38 & 1,32 & 4,83 & 0 \\
\hline
\end{tabular}

a. Dependent Variable: Earning per Share

Source: SPSS data processing results

1) Effect of Return on Assets to Earning per Share

Based on the calculation results, the $t_{- \text {count }}$ figure is obtained $-2,499>t$ table $_{\text {ta }}$ of 2.028 with sig $0.017<0.05$, which means there is a significant negative effect on the variable Return on Assets to Earning per Share. So H0 is rejected and $\mathrm{Ha}$ is accepted. The magnitude of the effect of the variable Return on Assets on Earning per Share of -0.683 which is shown by the magnitude of the $\beta$ value of the study is considered if the Return on Assets variable increases by 1 unit, then Earning per Share decreases 0.683.

2) The effect of Return on Equity on Earning per Share

Based on the SPSS results, $\mathrm{t}_{\text {- }}$ count figure of $4.830>\mathrm{t}_{\text {-table }}$ of 2.028 was obtained with a sig value of $0.000<0.05$, which means there was a significant positive effect on the Return on Equity variable on Earning per Share, so $\mathrm{H}_{0}$ was rejected and $\mathrm{H}_{\mathrm{a}}$ was accepted. The magnitude of the influence of the Return on Equity variable is 1,320 which is shown by the magnitude of the $\beta$ value of the study, meaning that if the Return on Equity variable increases by 1 unit, the Earning per Share increases by 1,320. Based on the results above, obtained the equation of Analysis Model Substructure 1 as follows:

$$
\begin{aligned}
& \mathrm{Y}_{1}=\beta \mathrm{Y}_{1} \mathrm{X}_{1}+\beta \mathrm{Y}_{1} \mathrm{X}_{2}+\mathrm{e}_{1} \\
& \mathrm{Y}_{1}=-0,683+1,320+(100-55,7 \%) \\
& \mathrm{Y}_{1}=-0,683+1,320+0,543 \\
& \mathrm{Y}_{1}=1,18
\end{aligned}
$$




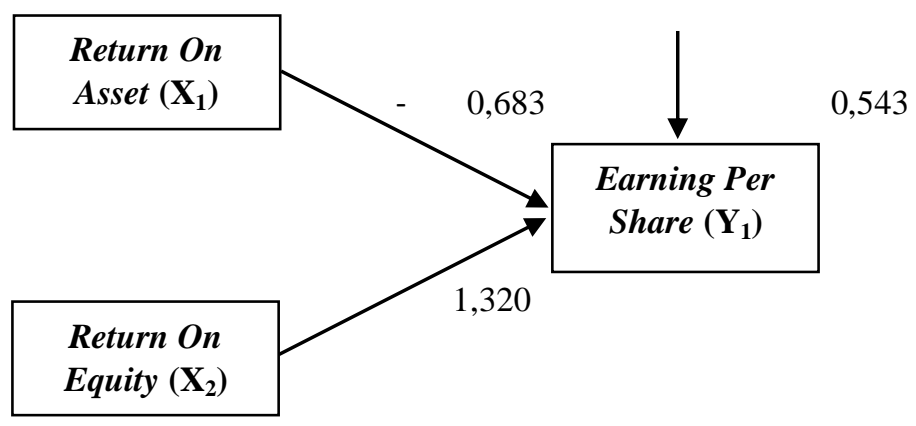

Fig. 3. Substructure results 1

This means that the Return on Asset variable affects Earning per share of -0.683 and the Return on Equity variable affects Earning per share by 1,320 while the value of 0.543 is caused by other variables outside this model.

2. Effect of Return on Assets, Return on Equity Earning per Share on Price Book Value (Substructure 2)

Table 10. Substructure t Test Results 2

\begin{tabular}{|c|c|c|c|c|c|c|}
\hline \multicolumn{7}{|c|}{ Coefficients $^{\mathrm{a}}$} \\
\hline \multirow{2}{*}{\multicolumn{2}{|c|}{ Model }} & \multicolumn{2}{|c|}{$\begin{array}{l}\text { Unstandardized } \\
\text { Coefficients }\end{array}$} & \multirow{2}{*}{$\begin{array}{c}\text { Standardized } \\
\text { Coefficients }\end{array}$} & \multirow[t]{2}{*}{$\mathrm{T}$} & \multirow[t]{2}{*}{ Sig. } \\
\hline & & $\mathrm{B}$ & Std. Error & & & \\
\hline \multirow{4}{*}{1} & (Constant) & $-0,087$ & 0,124 & & $-0,705$ & 0,486 \\
\hline & $\begin{array}{l}\text { Return On } \\
\text { Asset }\end{array}$ & $-0,052$ & 0,212 & $-0,055$ & $-0,247$ & 0,807 \\
\hline & $\begin{array}{l}\text { Return On } \\
\text { Equity }\end{array}$ & 0,834 & 0,258 & 0,852 & 3,23 & 0,003 \\
\hline & $\begin{array}{l}\text { Earning Per } \\
\text { Share }\end{array}$ & $-0,863$ & 0,088 & $-1,216$ & $-9,79$ & 0 \\
\hline
\end{tabular}

a. Dependent Variable: Price Book Value

Source: SPSS data processing results

1. Effect of Return on Assets on Price book value

Based on the results of calculations, the $t_{- \text {count }}$ figure was $-0.274<t_{-t a b l e}$ of 2.028 with a sig value of $0.807>0.05$ so that $\mathrm{H}_{0}$ was accepted and $\mathrm{Ha}$ was rejected. That is, there is no influence and insignificant variable Return on Assets on Price book value.

2.The effect of Return on Equity on Price book value

Based on the SPSS results, the t-count figure was 3.230> $\mathrm{t}_{\text {-table }}$ of 2.028 with a sig value of $0.03<0.05$ so that $\mathrm{H}_{0}$ was rejected and $\mathrm{H}_{\mathrm{a}}$ was accepted. That is, there is a significant influence on the Return on Equity variable on Price book value. The magnitude of the influence of the Return on Equity variable of 0.852 which is shown by the magnitude of the $\beta$ value of the study, means that if the Return on Equity variable rises by 1 unit, then the Price book value rises 0.852 . 
3.Earning per Share influence on Price book value

Based on the calculation results, the calculated $t_{-}{ }_{\text {count }}$ is $9,790>t^{-}{ }_{\text {table }}$ of 2,028 with a sig value of $0,000<0.05$ so that $\mathrm{H}_{0}$ is rejected and $\mathrm{H}_{\mathrm{a}}$ is accepted. That is, there is a significant negative effect of Earning per share variable on Price book value. The magnitude of the effect of Earning per share variable on the Price book value of $-1,216$ which is shown by the magnitude of the $\beta$ value of the study, means that if the Earning per share variable goes up by 1 unit, the Price book value decreases by 1.216

Based on the results of the SPSS, the equation of Analysis Model Substructure 2 is obtained as follows:

$$
\begin{aligned}
& \mathrm{Y}_{2}=\beta \mathrm{Y}_{2} \mathrm{X}_{1}+\beta \mathrm{Y}_{2} \mathrm{X}_{2}+\mathrm{e}_{1} \\
& \mathrm{Y}_{2}=-0,55+0,852+(100 \%-73,3 \%) \\
& \mathrm{Y}_{2}=-0,55+0,852+0,267 \\
& \mathrm{Y}_{2}=0,569
\end{aligned}
$$

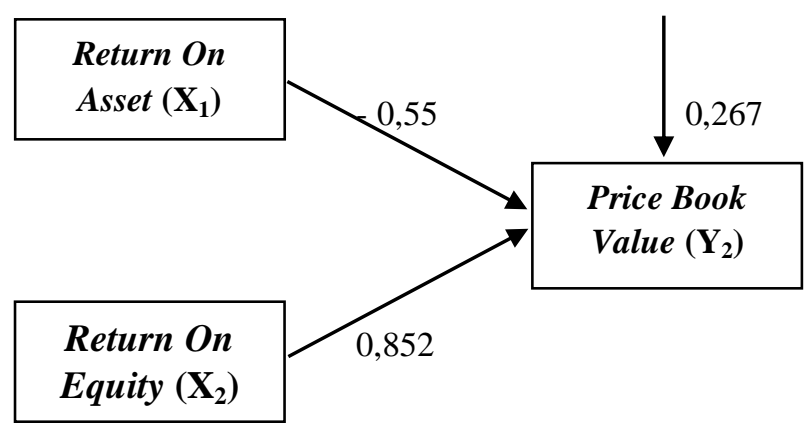

Fig. 4. Substructure Results 2

This means that the Return on Asset variable influences the Price book value of - 0.55 and the Return on Equity variable influences the Price book value of 0.852 while the value of 0.267 is caused by other variables outside this model. Thus, overall the path diagram model (Path Analysis) can be described as follows:

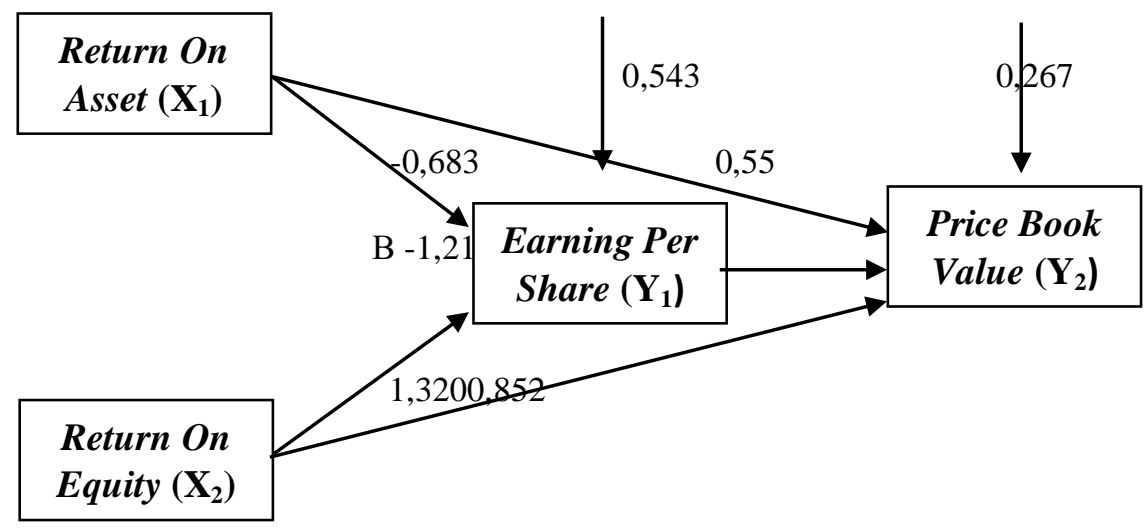

Fig. 5. Path Diagram Model 


\section{Discussion}

\section{Effect of Return on Assets on Earning Per Share}

Based on the results of the statistical test t (t-test) resulted in a count of - 2,499> t-table of 2,028 with sig $0.017<0.05$ and a significant negative effect on Earning per Share. This means that there is an effect of Return on Assets on Earning per Share in the company construction sub-sector with a $\beta$ value of -0.683 . A negative $\beta$ value means that if the Return on Assets variable increases by 1 unit, then Earning per Share decreases by 0.683 . This is because the lower ROA shows the company'spperformance is decreasing because the rate of return on investment in total assets is getting lower. The lower the rate of return on investment in total assets, the lower the change in stock prices. A negative return on assets indicates that the total assets used do not provide benefits for the company or loss.

This is in line with research conducted by Rafika Diaz and Jufrizen (2014) which states that Return on Assets do not affect Earning Per Share. But contrary to research conducted by Nurcholidah (2017) which says Return on Assets has an influence on Earnings Per Share. The insignificance of the variable Return on Assets makes investors not pay attention to Return on Assets in their investment decisions because Return on Assets has a weakness that tends topfluctuate up and down.

\section{Effect of Return on Equity on Earning per Share}

Based on the results of the statistical test $t$ (t-test) yielded 4,830>t-table of 2,028 with a sig value of $0,000<0.05$ which means there was a significant positive influence on the variable Return on Equity on Earning per Share. This means that there is an effect of Return on Equity on Earning per Share in the construction sector sub-company with. B value of 1.320 which means that if the Return on Equity variable increases by 1 unit, the Earning per Share rises by 1,320. Positive Return on Equity will affect the increase in company value. Return on equity is one of the factors that earns earnings per share(Husnan, 2001). This result is in line with research conducted by Lestiningsih (2017) who said that there is a positive and significant effect of Return on Equity on Earning per Share.

\section{Effect of Return On Assets on Price Book Value}

Based on the results of the statistical test $t$ (t-test) produces $-0.274<t$-table of 2.028 with a sig value of $0.807>0.05$ which means that the Return on Asset variable has no effect and is not significant on Price Book Value. This means that there is no Return effect on Asset of Price Book Value in companies in the building construction sub-sector with a $\beta$ value of -0.55 . Based on the theory of Return on assets is the ratio used to measure the ability of companies to generate profits derived from investment activities. The greater the Return on assets, the greater the level of excellence achieved by the company and the better the company's position in terms of asset use (Mardiyanto, 2009). Overall the sample can be said that financial performance based on raiso profitability is quite good, but at Ascet Indonusa Tbk and Adhi Karya (Persero) Tbk companies have a low average Return on Assets ratio. Both during the period 2015 to 2018 the value of Return on Assets fluctuated. In the Ascet Indonusa Tbk company has an average value of ROA during 2015 to 2018 is 2.24 while Adhi Karya (Persero) Tbk is 1.83 . The average value is smaller than 8 other companies.

This value means that the average performance based on ROA is very poor, this is due to the company suffering losses. Return on Assets is derived from net income after tax divided by Total Assets. The low profit of the company is caused by the funds incurred for the company's operations which are not in accordance with the profit obtained. If the company uses the overall funds for operations to the maximum or in accordance with the needs of the company, the profit obtained will be the maximum result. However, if tested with a path analysis of Return on Assets through Earning Per Share has a significant effect on Price Book Value. This can be seen from the large indirectpeffect of Return On Assets through Earning Per Share on Price Book Value of 0.830 which is greater than the direct effect.The results of this study are in line with research conducted by Oktrima (2017) which states that profitability which is proxied by return on assets (ROA) does not affect the firm value proxied by Price Book Value (PBV), but is contrary to research by Halimah and Komariah (2017) return on assets has a significant effect on firm value. 


\section{Effect of Return on Equity on Price Book Value}

Based on the results of the statistical test $t$ (t-test) produces a t-test of 3.230>t-table of 2.028 with a sig value of 0.03 $<0.05$. This means that the veriable Return on Equity has a positive and significant effect on the Price book value in the Building Construction sub-sector Company with a $\beta$ value of 0.852 . Means that if the Return on Equity variable increases by 1 unit, themPrice book value increases by 0.852 . This happens because the average company in this study has a value of equity greater than the value of profit after tax which causes the value of ROE. The amount of ROE shows the amount of return on investors that will be received, hence the ROE indicator is considered to influence investment decisions for investors which causes investor confidence in the company to increase and investors are interested in buying company shares. The results of this study are in line with the research carried out by Michael \& Ruslim (2019) which states that Retrun on equity affects the price book value.

\section{Effect of Earning Per Share on Price Book Value}

Based on the results of the statistical test $t$ (t-test) produces a t-test of 9,990>t-table of 2,028 with a sig value of $0,000>0.05$ that the Earning per Share variable has a negative and significant effect on the Price book value. This means that there is a negative influence of Earning per Share on Price Book Value in companies in the Construction Construction sub sector with a $\beta$ value of -1.216 . The research data shows that the value per share has experienced significant fluctuations in the period and the results of this study indicate that there is a negative relationship where when Earning per Share experiences an increase, the value of the Price book value actually decreases (and vice versa). Earnings information shown through Earning per Share does not reflect the stock price which is the basis for calculating company value.

The results of this study are in line with Pioh, Tommy \& Sepang (2018) which states that Earning per Share has no positive effect on Price book value, but contrary tomresearch conducted by Septiani and Wijaya (2018) which states that Earning per Share (EPS) a positive and significant effect on price to book value (PBV).

\section{Conclusion}

Based on the results of the data analysis and discussion described in the previous chapter, the conclusions of this study are:

1. The results of this study prove that Return on Assets has a negative and significant effect on Earning per Share

2. The results of this study prove that Return on Equity has a positive and significant effect on earnings per Share

3. The results of this study prove that Return on Assets have no effect and are not significant on Price Book Value

4. The results of this study prove that Return on Equity has a positive and significant effect on Price Book Value

5. The results of this study prove that Earning per Share has a negative and significant effect on Price Book Value

This study only measures financial performance and firm value by using the independent variable Return on Asset and Return On Equity. If there are other independent variables that are used to measure Earning per Share and Price Book Value, therefore the measurement of price book value can be measured with other independent variables, and only applies to the Construction Construction sub-sector companies listed on the Indonesian stock exchange using report data financial year of $2015-2018$.

Henceforth research on company value can be expanded with independent variables other than the independent variables above and with research objects outside the building construction company.

\section{References}

Abd'rachim. (2008). Manajemen Keuangan. Jakarta: Nobel Edumedia.

Achmad, E., Kuncoro, \& Riduwan. (2014). Cara Menggunakan dan Memakai Path Analysis (Analisis Jalur). In Cetakan ke-6. Bandung: Alfabeta.

Ang, R. (1997). Buku Pintar Pasar Modal Indonesia. Jakarta: Mediasoft Indonesia. 
Brigham, Eugene, \& F.Houston, J. (2006). Financial, Fundamental Of Management, Dasar - Dasar Manajemen. In A. B. oleh A. A. Yulianto (Ed.), Buku satu (Edisi Sepu, p. 19). Jakarta: PT. Salemba Empat.

Diaz, R. (2008). Pengaruh Return on Assets (ROA) dan Return on Equity (ROE) terhadap Earning Per Sahre pada Perusahaan Asuransi yang terdaftar di Bursa Efek Indonesia. Encyclopedia of Finance, 14(2), 233-233. https://doi.org/10.1007/0-387-26336-5_1736

Ghozali, I. (2011). Aplikasi Analisis Multivariate Dengan Program SPSS. Semarang: Badan Penerbit Universitas Diponegoro.

Halimah, S. N., \& Komariah, E. (2017). Pengaruh Roa, Car, Npl, Ldr, Bopo Terhadap Nilai Perusahaan Bank Umum. JURNAL AKUNTANSI, EKONOMI Dan MANAJEMEN BISNIS, $5(1), 14$ https://doi.org/10.30871/jaemb.v5i1.448

Husnan, S. (2001). Dasar-dasar Teori dan Analisis Sekuritas (Edisi Keti). Yogyakarta: UPP AMP YKPN.

Husnan, S. (2004). Dasar-dasar Teori Portofolio dan Analisis Sekuritas. In Edisi Ketiga. Yogyakarta: UPP AMP YKPN.

Kasmir. (2012). Analisis Laporan Keuangan. Jakarta: PT. Raja Grafindo Persada.

Lestiningsih, A. S. (2017). Pengaruh ROA dan ROE Industri Farmasi terhadap Earning Per Share. 25-29.

Mardiyanto, H. (2009). Intisari Manajemen Keuangan. Jakarta: Gasindo.

Margaretha, F. (2007). Manajemen Keuangan (Edisi Kedu). Jakarta: Gramedia Widiasarana Indonesia.

Michael, \& Ruslim, H. (2019). The Effect Of Financial Ratio On Company Value With Inflation As A Moderation Variable. Jurnal Akuntansi, 23(1), 33. https://doi.org/10.24912/ja.v23i1.458

Oktrima, B. (2015). Modal Terhadap Nilai Perusahaan. 1(2581), 98-107.

Pardede, R., \& Manurung, R. (2014). Analisis Jalur (Path Analysis) Teori dan Aplikasi dalam Riset Bisnis.

Pioh, H. T., Tommy, P., \& Sepang, J. L. (2018). Pengaruh Debt To Equity Ratio, Earning Per Share Dan Return on Asset Terhadap Nilai Perusahaan Sub Sector Food and Beverages Di Bursa Efek Indonesia. Jurnal EMBA: Jurnal Riset Ekonomi, Manajemen, Bisnis Dan Akuntansi, 6(4).

Septiani, I. D., \& Wijaya, I. (2018). Pengaruh ROA, LTDER , EPS dan Economic Entity Terhadap Price to Book Value Pada Perusahaan Farmasi. 5(1).

Sriyono, Prapanca, D., \& Budi, B. S. (2019). Analisis Return On Equity (ROE), Current Ratio (CR), Net Profit Margins (NPM), Dan Debt To Equity Ratio (DER) Terhadap Earning Per Share (EPS). JBMP (Jurnal Bisnis, Manajemen Dan Perbankan), 4(2), 95-163.

Sugiyono. (2009). Metode Penelitian Kuantitatif, Kualitatif dan R\&D,. Bandung: Alfabeta.

Wahyuningsih, P., \& Widowati, D. M. (2016). Analisis ROA dan ROE terhadap Nilai Perusahaan dengan Corporate Social Responsibility sebagai Variabel Moderating (Studi Pada Perusahaan BUMN yang terdaftar di BEI Periode 2010-2013). Jurnal STIE SEMARANG, 8(2), 4-7.

Wild, J., \& Subramanyam, H. (2005). Analisis Laporan Keuangan. In Buku 1 (Edisi ke-8). Jakarta: Salemba Empat. 